\title{
Victimization and pain
}

\section{Przemoc a ból}

\author{
Małgorzata K. Szerla ${ }^{1,2}$, Dorota E. Ortenburger ${ }^{3,4}$ \\ ${ }^{1}$ Department of Emergency Medicine, Faculty of Health Sciences, Jan Kochanowski University, Kielce, Poland \\ Head of Department: Prof. Siarhei Panko MD, PhD \\ ${ }^{2}$ The Provincial Specialist Children's Hospital, Kielce, Poland \\ Head of Department: Małgorzata Szerla MD, PhD \\ ${ }^{3}$ Department of Social Sciences, Jan Długosz Academy, Częstochowa, Poland \\ Dean of Academy: Prof. Romuald Derbis PhD \\ ${ }^{4}$ The Pain Treatment Centre, Częstochowa, Poland \\ Head of Department: Piotr Kurpiś MD
}

Key words: violence, victim, psychosomatic disorder, pain.

Słowa kluczowe: przemoc, ofiara, zaburzenia psychosomatyczne, ból.

\begin{abstract}
Pain has several causes. It can be caused not only by operative trauma or cancer. Some patients suffer from pain as a result of being victims of violence. The aim of the study was to introduce diagnosis and treatment of pain problems in patients who are victims of violence, from a physician's and a psychologist's common perspective. Physical pain-related primary effects experienced by the victims of domestic violence go far beyond the results which are noticeable directly and confirmed visually in a forensic examination. In the present paper we introduce an 'invisible' group of secondary effects of violence. They appear in time, often after several years, in the form of a variety of psychosomatic disorders. The body is devastated insidiously and the secondary effects are visible as vegetative symptoms, a variety of psychosomatic disorders and pain, difficult to diagnose and treat.
\end{abstract}

\section{Streszczenie}

Ból miewa wiele przyczyn. Może być spowodowany nie tylko przez uraz operacyjny czy nowotwór. Niektórzy pacjenci cierpią z bólu, bo są ofiarami przemocy. Celem pracy jest przybliżenie problemów diagnozowania i terapii bólu u pacjentów będących ofiarami przemocy z perspektywy lekarza i psychologa na podstawie literatury przedmiotu oraz własnych doświadczeń zawodowych. Konsekwencje bólu pierwotnego jako efektu przemocy domowej wykraczają poza widoczne bezpośrednio (potwierdzone obdukcją) skutki fizyczne. W niniejszym artykule przedstawiono zespół wtórnych (nieuchwytnych gołym okiem) skutków przemocy, ujawniających się często po kilku latach w postaci różnych zaburzeń psychosomatycznych. W niszczonym podstępnie organizmie pojawiają się wtórnie objawy wegetatywne, różne zaburzenia psychosomatyczne oraz trudny do zdiagnozowania i leczenia ból.

We deserve this - the message which we convey to ourselves is one of the most destructive effects of being treated violently (excerpt from the book "The effect of fading light. How to cope with emotional violence" by R. Stern)

\section{Introduction}

The word 'pain' comes from the Latin poena, which means punishment or penalty, after the Roman goddess of punishment. Originally, the term was used for the punishment for an offence against the law. Over time the word was increasingly used to denote suffering, particularly if this had resulted from a blameworthy act. Emotional suffering was equated with pain. Thus, pain has been of minor importance to medical science, leaving that phenomenon to philosophers or theologians for centuries [1]. The origin of the theory that the transmission of pain is through a single channel from the skin to the brain descends from the seventeenth century philosopher and scientist René Descartes. This simplified scheme of the reflex was the beginning of the development of the modern doctrine of reflexes. Unfortunately, since Cartesian times pain has been perceived as a direct way of conducting impulses, whereas the psychological dimension of 
the pain experience was largely forgotten. Therefore, scholars were trying to find simple means of eliminating pain. Descartes' reflex theory prevailed over both the study and treatment of pain for over 330 years [2]

It was only in 1946 that Bonica claimed that a pain patient should be managed interdisciplinarily and he was the first scientist who applied that approach. He presented his scientific view of such an individual and complex phenomenon in his pioneering book Management of Pain (1953), and in 1960, he founded a multi-specialty pain relief clinic. He was also the founder of the International Association for the Study of Pain (IASP) in 1974. Although the concept of multi-specialty pain management came into view a long time ago, commonly, pain is associated with directly experiencing physical trauma. Therefore, it may seem that healing physical wounds of the body should end pain-related ailments.

The consensus of IASP experts (specialist physicians and psychologists) came up with the definition of pain on the basis of two equivalent components: receptor (physis) and emotional (psyche). Thanks to that it has been proved that neurophysiological, neurochemical and neuroimmunological processes of many structures of the central nervous system are engaged in that complex phenomenon. That knowledge must be included when we consider the victimization process.

In the present paper, we highlight that group of preserved and accumulated effects of violence which are frequently concealed and the victims do not often realize how drastically they influence their functioning, both mental and somatic. Overcoming those effects can be a long-lasting and painful process.

Trauma which cannot be coped with by the victims themselves is believed to be a predictor of the risk of accumulating problems in a variety of aspects of life.

\section{Victimization}

Victimization is an act that exploits or victimizes someone treated unfairly. Long-lasting negative emotions, humiliation and hurting one's sense of dignity cause that violence victims develop in themselves pain and health problems, family problems and social malfunctioning. This is the result of chronic stimulation of the structures of the central nervous system, e.g. vegetative, emotion, endocrine and immune centres [3].

Physical pain-related primary effects experienced by the victims of domestic violence go far beyond the results which are noticeable directly and confirmed visually in a forensic examination. There is an 'invisible' group of secondary effects of violence. In the early peri-trauma period they are either invisible or hard to detect as both the perpetrator and the victim conceal them for a long time. This is most often caused by fear of the consequences (on the part of the perpetrator) as well as by shame, anxiety or lack of awareness that a remedy can be found (on the part of the victim).

If the perpetrator who inflicted physical and mental pain is a family member, someone closely related to the victim, recognizing those disorders is especially difficult. Pain inflicted by a loved one causes suffering which touches the deepest layers of human identity. This is trauma which cannot be overcome by the victims themselves, without somebody else's (specialist) help. The consequences of the victimization process are not limited to the results confirmed, e.g. during a forensic examination. Long-term results of such a condition influence the quality of an individual's psychosomatic functioning. The knowledge about destructive health effects of (domestic) violence keeps increasing [4].

Violence can assume more or less drastic forms. The effects of repressive actions on the victims of violence are not always the ones which are visible with the naked eye. Consequently, the perpetrators often feel they can go unpunished. This is due to the fact that the victims do not react properly because they feel shame before their community and fear of the perpetrator, and they minimize or hide injuries which they suffered and which are not always visible. Simultaneously, the victims of violence very seldom go to hospital or to a forensic examination on their own volition. Thus, if there is not any proof to confirm what the victim claims, another case of violence disappears and is forgotten.

Secondary effects of a concealed trauma are developing and preserving, and they often influence the whole body tragically. It is hard to see the secondary consequences of such traumas by means of a basic examination tool applied in medical and psychological practice, which is a clinical interview $[5,6]$.

\section{Domestic violence}

The process of becoming a victim is always about a specific person who experiences unjustified harm, pain and suffering. All types of violence are considered from the moral, social and legal perspective. However, theoreticians of domestic violence emphasize primarily the area of its disclosure. They put much less emphasis on the victim's personality characteristics.

Domestic violence can be defined as a pattern of behaviour in any relationship that is used to gain or maintain power and control over an intimate partner. Differentiation between the forms of violence is mainly of ordering importance. In reality, we deal most often with a combination of different types of violence. Referring to the classification which is frequently applied, the definition 'domestic violence' does not emphasize the results but just the context of 
the incidence of violence, which is disadvantageous for the core of the problem.

Physical violence includes a variety of behaviours, some of which are classified as a criminal act. When the pressure of violence occurs in the family which is the natural environment where a personal identity is shaped, those incidents may not be revealed for a long time. This phenomenon reflects the idea of 'washing one's dirty linen at home.'

The neuroscientific dimension of a person's functioning allows us to deepen the analysis of the victimization process. From that perspective, one can notice the connection between an individual's biology and his/her life story being formed. A person's painful physical experience as well as negative emotions and pain accompanying it constitute a measurable destructive victimization process. The results of the destructive victimization process manifest themselves through the difficulties for the victims in realizing their own potential. They also influence significantly the shape of the victims' further lives.

Domestic violence can happen to anyone. It includes many forms of abuse such as physical, sexual, emotional, economic or psychological actions influencing another person.

This is expressed by a variety of behaviours that frighten, intimidate, terrorize, manipulate, hurt, humiliate, blame, injure or wound an individual. It can happen to couples who are married or in an informal relationship and their offspring. Domestic violence affects people of all socioeconomic backgrounds and education levels.

Psychologists generally analyze the phenomenon of violence in a family environment. The findings of contemporary research prove that experiencing recurring acts of violence in the family contributes to the development of long-lasting mental disorders in its victims. Paradoxically, privacy makes favourable conditions for the perpetrator, who feels he will go unpunished for the simple reason that the violence occurs within commonly respected borders - the home. Hence, the perpetrator has impunity to use violence without any witnesses, "within his own four walls."

The majority of studies are devoted to the consequences of violence against women. We should bear in mind, however, that children can experience battering just as much, not only in the form of abuse or neglect. The findings prove that children do suffer and are harmed when they are passive witnesses of violence inflicted by adults. Children undergo the process of victimization by participating in pathological events happening in their families. Coming into contact with violence in a theoretically friendly environment, they acquire the pattern of communicating with others via violence, conflicts and relationships based on constraint. Victimization of children happens through their emotional engagement on the lev- el of neurophysiological structure. In the brain there are areas called mirror neurons enabling emotional consonance with other individuals and participating in this complex process. They are called empathy neurons for the role they play - they provide intuitive knowledge about other people's intentions and they enable co-feeling of their emotions (joy, sadness, anxiety) and pain. Mirror neurons are part of a hitherto unrecognized "sixth sense" [7-10].

Since time immemorial it has been observed that physical pain just as mental suffering weakens a person's spirit. In extreme cases it may lead a person to become self-destructive. Contemporary findings in psychoneuroimmunology explain scientifically certain mechanisms underlying the process of immunity loss as a result of those traumatic experiences [11, 12].

\section{Psychosomatic picture of domestic violence from the perspective of neuroscience}

Research by Horner and Hamner (2002) conducted on individuals who suffered from traumatic experience indicates clearly that they suffer from changed dynamics of brain function coexisting with specific memory disorders. Increased functioning disorders in a few areas of the limbic system were described in patients with post-traumatic stress disorder. This also concerns the cortical central nervous system, which is connected with those areas functionally and anatomically. This phenomenon often results in deterioration of cortical control of the areas related to emotional processes and memory [13]. Processes of the above malfunctioning of the central nervous system concern both adult victims of violence and children growing up in an environment where violence prevails [14].

Collected evidence confirmed the hypothesis that this happens by way of lowering the efficiency of the immune system. Consequently, battered individuals are harmed not only at that specific moment but also in a more distant future. In the light of neurobiological knowledge, such experience influences future functioning of the nervous system controlling all of the body functions [15].

Neurophysiological mechanisms responsible for the havoc which is caused by trauma resulting from violence and pain have become better known owing to the knowledge spread by the International Association for the Study of Pain (IASP). Since the very beginning IASP has been dealing not only with studying the consequences of experiencing pain but it has also been emphasizing the nature of medical and psychological conditioning of the effectiveness of pain relieving therapy [16].

Understanding the phenomenon of pain has increased within the last thirty years owing to numerous findings in the area of neurophysiology, neuroendocrinology, and neuropsychology. Currently, there is also technical possibility of exposing areas and tracks 
where nociceptive processes take place by means of positron emission tomography (PET). Brain imaging tests in individuals suffering from recurring pain reveal pathological reduction of gray matter density in certain areas of the cerebral cortex [17-19].

However, these issues go far beyond the range of the present work. In our work we only draw the readers' attention to the problem of violence-related pain in the context of the results which come into being in the nervous system functioning in individuals who have experienced domestic violence.

\section{Final reflections}

The influence of the psyche on pain symptoms and vice versa has become widely recognized. The victim's dealing with victimization depends on many factors. Overcoming the consequences of victimization depends mainly on the victim's individual personality features. However, it is necessary to provide assistance in that respect. Working in the area of pain, we should devote our particular attention to people whose pain is the result of stress or psychological difficulties. Therefore, when we deal with individuals with chronic pain and with insufficient organic factors to explain suffering from pain, we should look carefully into psychological or even psychiatric explanations [1].

Child abuse is a pervasive problem in the contemporary world that has long-term detrimental consequences to the development of the affected child such as future brain growth and functioning. There is evidence for the neuropsychological effects of child abuse especially in emotional, behavioural, and cognitive process-response difficulties. The hypothalamic-pituitary-adrenal axis, the amygdala, the hippocampus, and prefrontal cortex are vulnerable brain regions which are responsible for children's compromised ability to process both emotionally laden and neutral stimuli in the future. The alteration of the biochemical stress response system in the brain changes an individual's ability to respond efficiently and efficaciously to future stressors. It is known as the traumatic stress response.

Abuse in childhood contributes to the development of adult pain syndromes. The hypothesis that childhood trauma predisposes individuals to develop pain conditions has been especially prominent for syndromes that involve pain of unknown origin together with psychological complaints. One such syndrome is fibromyalgia, in which widespread musculoskeletal pain is often accompanied by fatigue, sleep disturbance, and affective symptoms. Fibromyalgia is six to nine times more prevalent in women than in men $[20,21]$.

A long-lasting state of helplessness toward an individual using violence, such as inflicting physical pain, creating a continuous sense of insecurity and a sense of threat, as well as depriving someone of their sense of dignity and self-esteem, threatens the victim with their loss of personal integrity. Such a chronic destructive effect leads to preservation of unfavourable neurochemical changes within many areas of the central nervous system, influencing the further lives of the victims of physical and psychical violence [21].

The issue of violence prevention is dealt with differently in every region of the world. The differences concern, first of all, widely understood cultural background as well as a binding concept of authority and submissiveness governing in a specific country.

Also, individual countries present different levels of development in the recording system and reporting different aspects of violence. Those circumstances repeatedly influence the formation of attitudes of both the perpetrator and the victim.

Although those issues go far beyond the scope of the present paper, we want to draw the reader's attention to the necessity for the introduction of systemic changes to this problem. We realize that such solutions often require organic work. That work should include respect for the tradition, culture and religion of a specific region. At the same time, the work should be based on reliable scientific, medical, psychological and sociological analyses.

Reliable academic knowledge obtained as a result of the studies of attitudes, beliefs, behaviours, cultural habits, victimization and the degree of exposure to violence constitutes the turning point in solving that difficult issue. Unfortunately, the following question needs to be considered: how to solve the dilemma that although domestic violence resulting in pain and humiliation is legally a crime, strong pressure is observed to be exerted on keeping it secret.

Data concerning the population characteristics in terms of education level, employment and income are equally essential. Simultaneously, economic aspects connected with the cost of treatment, existence and activity of welfare centres as well as preventive actions should be considered. It is also necessary to define the risk factors, including family and environmental, which, in the future, may be the reason for a specific person's getting entangled in violence. He or she may become either a victim or a passive witness [22, 23].

Further studies considering the cultural context are purposeful. They lead to recognizing certain cultivated but unfair for an individual patterns, traditions or to fostering behaviours and attitudes which favour hiding abuse towards another person. However, solely identifying the sources of violence, its forms and conditionings, as well as consequences, is not enough for a radical solution of that important and widespread social phenomenon [24].

The neuroscientific aspect broadens and deepens understanding of dramatic, long-term consequences of experiencing violence. From a medical and psychological perspective, it is essential to consider looking 
into the pain problem in victims of violence in a content-related way.

\section{References}

1. Tyrer S. Psychosomatic pain. B J Psych 2006; 188: 91-93.

2. DeLeo JA. Basic science of pain. J Bone Joint Surg Am 2006; 88 (Suppl. 2): 58-62.

3. Wilson KR, Hansen DJ, Li M. The traumatic stress response in child maltreatment and resultant neuropsychological effects. Aggression and Violent Behavior 2011; 16: 87-97.

4. World Report on Violence and Health. Krug EG, Dahlberg LL, Mercy JA et al (eds.). World Health Organization, Geneva 2002.

5. Kosztołowicz M, Szerla M, Domański M. Propozycja konstrukcji języka komunikacji lekarz pacjent z uwzględnieniem bólu i osobowości pacjenta. W: Ból i cierpienie. Makiełło-Jarży G, Gajda Z (eds.). Acta Academiae Modrevianae. Krakowskie Towarzystwo Edukacyjne, Oficyna Wydawnicza AFM, Kraków 2008; 113-134.

6. Szerla MK, Ortenburger DE, Domański M, Tarnopolski A. Selected factors influencing the relationship between the physician and the patient with chronic pain. In: Janowski K, Steuden S (eds.). The multidisciplinary approach to health and desease. Selected papers. CPP Scientific Press Lublin 2011; 140-148.

7. Lohmar D. Mirror neurons and the phenomenology of intersubjectivity. Phenomenology and the Cognitive Sciences 2006; 5: 5-16.

8. Shmuelof L, Zohary E. Watching others' actions: mirror representations in the parietal cortex. Neuroscientist 2007; 13: 667-672.

9. Shapiro L. Making sense of mirror neurons. Synthese 2009; 167: 439-456.

10. Szerla M, Kosztołowicz, M. Funkcjonalność metody ewaluacji bólu w praktyce klinicznej - propozycje. In: Ból i cierpienie. Makiełło-Jarża G (ed.). Acta Academiae Modrevianae. Krakowskie Towarzystwo Edukacyjne, Oficyna Wydawnicza Akademii Frycza Modrzewskiego, Kraków 2011; 205-211.

11. Segerstrom SC, Miller GE. Psychological stress and the human immune system: a meta-analytic study of 30 years of Inquiry. Psychol Bull 2004; 130: 601-630.

12. Tosevski DL, Milovancevic MP. Stressful life events and physical health. Curr Opinion Psychiatry 2006; 19: 184-189.

13. Horner MD, Hamner MB. Neurocognitive functioning in posttraumatic stress disorder. Neuropsychol Rev 2002; 12 : 15-30.

14. Schore AN. Relational trauma and the developing right brain. An interface of psychoanalytic self psychology and neuroscience. Self and systems. Explorations in Contemporary Self Psychology 2009; 1159: 189-203.

15. Braquehais MD, Picouto MD, Casas M et al. Hypothalamic-pituitary-adrenal axis dysfunction as a neurobiological correlate of emotion dysregulation in adolescent suicide. World J Pediatr 2012; 8: 197-206.

16. Hadjistavropoulos T, Craig KD. Pain psychological perspectives. Lawrence Erlbaum Associates, Publishers Mahwah, New Jersey, London 2004.

17. Porro CA. Functional imaging and pain: behavior, perception, and modulation. Neuroscientist 2003; 9: 354-369.

18. Bingel U, Tracey I. Imaging CNS modulation of pain in humans. Physiology 2008; 23: 371-380.
19. Tracey I. Imaging pain. Br J Anaesth 2008; 101: 32-39.

20. Nicolson NA, Davis MC, Kruszewski Z et al. Childhood maltreatment and diurnal cortisol patterns in women with chronic pain. Psychosom Med 2010; 72: 471-480.

21. Clauw DJ, Ablin JN. The relationship between stress and pain: lesson learned from fibromialgia and related conditions. In: Current topic in pain. $12^{\text {th }}$ World Congress on Pain. IASP Press, Seatle 2008; 245-270.

22. Brennan IR, Moore SC, Shepherd JP. Risk factors for violent victimization and injury from six years of the britishcrime survey. Int Rev Victimol 2010; 17: 209-229.

23. Ortenburger D. Wpływ przemocy fizycznej na układ nerwowy i funkcjonowanie psychiczne. In: Przemoc. Kamiński T (red.). Roczniki Naukowe Caritas. Fundacja Pro Caritate, Warszawa 2007; 41-47.

24. Schelble J, Franks B, Miller M. Emotion dysregulation and academic resilience in maltreated children. Child and Youth Care Forum 2010; 39: 289-303.

\section{Address for correspondence:}

Małgorzata K. Szerla MD

Department of Emergency Medicine

Faculty of Health Sciences

Jan Kochanowski University

al. IX Wieków Kielc 19, 25-317 Kielce, Poland

Phone: +48 6033983091

E-mail: szerla@wp.pl 